\title{
Induction of Experimental Arthritis by Borrelial Lipoprotein and CpG Motifs: Are Toll-Like Receptors 2, 4, 9 or CD-14 Involved?
}

\author{
Stephen Batsford,", John Dunn ${ }^{2}$ and Michael Mihatsch ${ }^{3}$ \\ ${ }^{I}$ Department of Immunology, Institute of Medical Microbiology and Hygiene, Albert Ludwigs University Freiburg, \\ D-79104 Germany \\ ${ }^{2}$ Brookhaven National Laboratory, Upton, New York 11973, USA \\ ${ }^{3}$ Institute of Pathology, Kantonspital Basel, CH-4003 Switzerland
}

\begin{abstract}
Bacterial lipoproteins and CpG-DNA are ligands for Toll-Like-Receptors (TLR) 2 and 9 respectively. Both classes of molecules were reported to induce experimental arthritis in rodents following direct intra-articular injection. Here we studied: 1) whether arthritis induction by Quter surface (Lipo)protein A (OspA) (B.burgdorferi) involved the TLR-2 as well as the TLR-4 or the CD-14 receptors in addition, and 2) re-examined the arthritogenic potential of CpGDNA motifs in mice.

Following intra-articular injection of the test substances [20 $\mu \mathrm{g}$ recombinant, lipidated OspA; $1 \mathrm{nM}(6 \mu \mathrm{g})$ to $10 \mathrm{nM}(60 \mu \mathrm{g})$ synthetic CpG-DNA], inflammation was monitored by ${ }^{99} \mathrm{Tc}$ scintigraphy (ratio left/right knee joint uptake $>1.1$ indicates inflammation) and by histology.

Lipoprotein OspA induced severe, acute arthritis in TLR-2 ${ }^{+/+}$w.t. but not in TLR-2 ${ }^{-/}$mice $(\mathrm{p}<0.01)$. There were no significant differences in the severity of arthritis induced in TLR $-4^{+/+}$w.t. and TLR $-4^{-/-}$mutant mice, or between CD $14^{+/+}$ w.t. and $\mathrm{CD} 14^{-/-}$mice.

CpG-DNA (1 or $10 \mathrm{nM}$ ) did not cause notable inflammation in C57BL/6 mice; ${ }^{99} \mathrm{Tc}$ ratios were $<1.0$ and histology showed only minimal changes.

Induction of arthritis by the OspA lipoprotein of B.burgdorferi involves the TLR-2 receptor, no evidence for additional participation of TLR-4 or CD14 receptors was found. Intra-articular injection of CpG-DNA did not produce manifest joint injury in mice, at variance with previous reports.
\end{abstract}

Keywords: Lipoprotein, arthritis, lipidated Osp A, CpG, CD-14, TLR-2, 4, 9.

\section{INTRODUCTION}

In reactive arthritis exposure to an infectious agent precedes the development of synovial inflammation. This event may arise as a local response of cells to microbial products within joints; presumably either as an antigen driven event or following recognition of pathogen-associated molecular patterns (danger signals) by appropriate pattern recognition receptors [1].

The Toll-like receptor family (TLRs) mediates signal transduction induced by many pathogen-associated molecular patterns (PAMPs), linking innate and adaptive immunity [2]. Some TLRs respond to diverse agonists, others are more specific, and the major signalling pathways include myeloid differentiation factor 88 (MyD88), TIRAP (Mal), TRIF and TRAM [2]. MyD88 dependent pathways are used by all TLRs except TLR-3 and activate the transcription factor NF- $\kappa B$ and MAPK families. Alternative, TRIF dependent pathways, are used by TLR-3 and TLR-4 to activate IRF3 and NF-KB.

\footnotetext{
*Address correspondence to this author at the Department of Immunology, Institute of Medical Microbiology, Hermann-Herder-Strasse 11, University Hospital Freiburg, D-79104 Freiburg, Germany;

Tel: ++ 49-761-203-6552/20; Fax: ++ 49-761-203-6577;

E-mail: stephen.batsford@uniklinik-freiburg.de
}

A major model for studying Lyme arthritis is the Vaccination-Challenge system, reviewed in [3]. In this model immunisation with intact, killed B. burgdorferi is generally followed by local challenge with viable organisms. However, the model can be adapted by using antigenic extracts of $B$. burgdorferi to provide specific information on particular components. Working along these lines, we previously showed that outer surface lipoproteins (Osp) from $B$. burgdorferi could in fact induce severe arthritis in rodents following intra-articular injection $[4,5]$, even without prior sensitisation to this molecule. Since borrelial Osps are known to activate cells via TLR-2 [6], we tested whether this receptor was involved in the model described [5]. CD-14 is a co-receptor for LPS, along with TLR-4. CD-14 can bind LPS only in the presence of LBP and CD-14 also recognises other pathogen-associated molecular patterns $[7,8]$. This prompted us to look for evidence whether CD-14 or TLR-4 receptors were involved.

Injection of bacterial DNA and oligonucleotides (ODN) containing unmethylated $\mathrm{CpG}$ motifs directly into the knee joints of mice has been reported to induce arthritis [9], presumably via TLR-9 engagement [10]. In further experiments, we re-examined the effect of local activation of TLR-9 in joints by appropriate ODNs to assess the potential 
role of this receptor-ligand interaction in post-infectious arthritis.

\section{MATERIALS AND METHODS}

Test Substances. Recombinant, full length, lipidated outer surface protein A (Osp A) was prepared from the Borrelia burgdorferi isolate $\mathrm{B} 31$ as previously described [11]. Preparations were screened for contamination with LPS by the Limulus coagulation test (Acila, Frankfurt, Germany); concentrations were 0.1 to $0.2 \%$, equivalent to 20 to $40 \mathrm{ng}$ LPS per $20 \mu \mathrm{g}$ Osp A.

The unmethylated oligonucleotide containing the $\mathrm{CpG}$ motif (ODN 1668) was obtained from TIB MOLBIOL (Berlin, Germany).

Animals. Adult male C57BL/6 mice were obtained from Harlan, Borchen, Germany. TLR-2 ${ }^{-/}$mice were on a 129SvJxB57BL/6 background [12] (gift of Carsten Kirschning, Munich, Germany with permission from Amgen, San Francisco, USA). TLR-4 mice were the C57B10ScN mutant, the intact strain was C57B10ScSN (gift of Marina Freudenberg, Freiburg, Germany). CD-14 ${ }^{-/-}$mice were on a CBAx129Sv background [13] (gift of Bob Jack, Greifswald, Germany, originally bred by Mason Freeman, Harvard, USA). Mice were housed in a conventional unit.

Arthritis induction. $20 \mu \mathrm{g}$ of lipidated Osp A (in $20 \mu \mathrm{l}$ of buffer) was injected directly into the left knee joint, the contra lateral right knee joint received $20 \mu 1$ of buffer alone as a control. In the case of synthetic $\mathrm{CpG}$ motifs (ODN $1668)$, either $1 \mathrm{nM}(6 \mu \mathrm{g})$ or $10 \mathrm{nM}(60 \mu \mathrm{g})$ were injected into the left knee joint in $20 \mu \mathrm{l}$ of buffer.

Technetium-99m scintigraphic uptake measurements. Joint inflammation was assessed by comparing ${ }^{99 \mathrm{~m}} \mathrm{Tc}$ pertechnate uptake between knee joints $[14,15]$. This technique measures joint swelling (edema) as an alternative to caliper measurements and correlates well with histologic scoring [16]. Each mouse received $1 \mathrm{MBq}$ of ${ }^{99 \mathrm{~m}} \mathrm{Tc}$ in $0.1 \mathrm{ml}$ of PBS, subcutaneously into the neck region. Gamma radiation emanating from both knee joints of the hind legs was measured using a collimated photoscintillation crystal. The hind legs were held in a defined position and the bodies were shielded with a lead screen. Radioactivity was measured 3 times over each joint in an alternating manner, for a duration of 0.5 minutes, and the mean values were used to calculate the left:right $(\mathrm{L}: \mathrm{R})$ ratio.

Histology. In each group studied 2 animals were killed at days 1-2 and 7 after intra-articular challenge for histological examination. Knee joints were detached and fixed in $4 \%$ buffered formalin, decalcified and embedded in paraffin. Standard frontal sections of the joints were stained with hematoxylin and eosin.

B-cell stimulation. The ability of $\mathrm{CpG}$ containing oligonucleotides to induce blast formation of B-cells was examined in culture. Spleen cell suspensions were prepared from C57-BL6 mice and cultures were set up in microtiter plates. Each well contained $1 \times 10^{5}$ cells in $200 \mu 1$ of IMDM medium, $1 \mu \mathrm{M}$ of the test ODN was added and after $70 \mathrm{~h}$. cells were harvested, washed and stained with antiCD45R/B220 Pan B-cell antibody (BD Pharmingen). Cells were analyzed by FACS, plotting intensity of antibody staining against forward scattering.
Statistical analysis. Data from scintigraphic measurements revealed inhomogeneity of variance and were subjected to a log-log transformation. By means of a Repeated Measures Analysis of Variance, differences between groups (between effect) as well as differences between days (within effect) were analysed. Pairwise comparison of groups was performed using Tukey's studentized range test. Differences between groups on single days (within effect) were confirmed by a Kruksal-WallisTest, followed by a Closed Test Procedure. $P$ values less than 0.05 were considered to be statistically significant (General Linear Models Procedure and NPAR1WAY, SAS 8.2 statistics packet and SAS-Macros).

\section{RESULTS}

The first set of experiments examined the role of TLR-2 in the induction of arthritis in mice by borrelial lipoprotein. Acute arthritis could be induced in w.t. $129 \mathrm{SvJxB} 57 \mathrm{BL} / 6$ mice $(\mathrm{N}=8)$ following intra-articular injection of lipidated, recombinant Osp A; the severity of the injury was dramatically ameliorated in TLR-2 KO mice $(\mathrm{N}=10)$. Differences in intra-articular uptake of $99 \mathrm{~m}$ Technetium between w.t. and KO mice were significant at days 1,2 and 7, as shown in Fig. (1a). On visual examination, pronounced knee joint swelling was seen only in w.t. mice. In w.t. mice, histological study revealed acute inflammation between days 1 and 2, characterised by massive swelling and cellular infiltration of the synovial membrane together with focal destruction of the cartilage surface (Fig. 2a, b); polymorphonuclear granulocytes were the major component of the cellular infiltrate. By day 7 the swelling had subsided and only discrete areas of infiltration were found. The TLR-2 KO mice revealed very mild arthritic changes at day 1 only, by day 2 joint tissue appeared normal (Fig. 2c).

We found no evidence of involvement of TLR-4 in the model used. Severe, acute arthritis could be induced in both intact $(\mathrm{N}=8)$ and TLR-4 deficient mutant C57B10 mice $(\mathrm{N}=9)$, there were no significant differences in the intraarticular uptake of $99 \mathrm{Tc}$ at any timepoint (Fig. 1b). The histological changes seen at days $1 / 2$ and 7 were similar in intact and mutant mice and closely resembled those seen in w.t. mice in the TLR-2 experiments described above.

Further experiments examined the role of CD-14. Severe, acute arthritis could be induced in both w.t. CBAx129Sv (N $=8)$ and $\mathrm{CD}-14 \mathrm{KO}$ mice $(\mathrm{N}=7)$, there were no significant differences in the intra-articular uptake of 99Tc at any time point (Fig. 1c), although the highest individual values were seen in w.t. mice. The histological changes seen at days $1 / 2$ and 7 were similar in w.t. and $\mathrm{KO}$ mice and closely resembled those seen in w.t. mice in the TLR-2 experiments described above.

The second part of the study re-examined the role of $\mathrm{CpG}$ motifs in the induction of experimental arthritis. Stimulation of TLR-9 by GpG motifs was reported to induce transient arthritis in C57BL/6 mice [9], characterised by an influx of monocytes. Using the same ODN (1668) at doses of both 6 and $60 \mu \mathrm{g}$ in $\mathrm{C} 57 \mathrm{BL} / 6$ mice $(\mathrm{N}=5)$, as in the original report [9], we were unable to find evidence of joint injury. 99Tc ratios between knee joints never exceeded the normal range over a 14 day period (Fig. 1d), visible joint swelling was absent and no histological abnormalities were seen at $1 / 2$ 
Fig. 1a

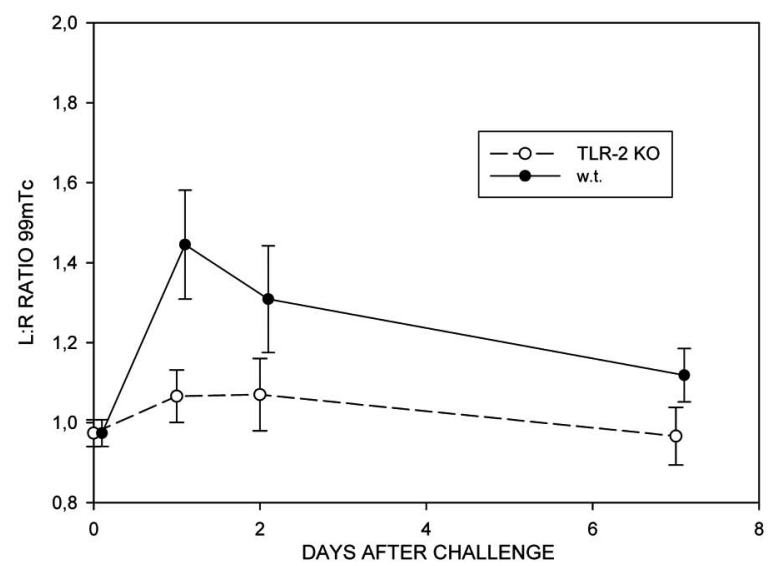

Fig. 1b

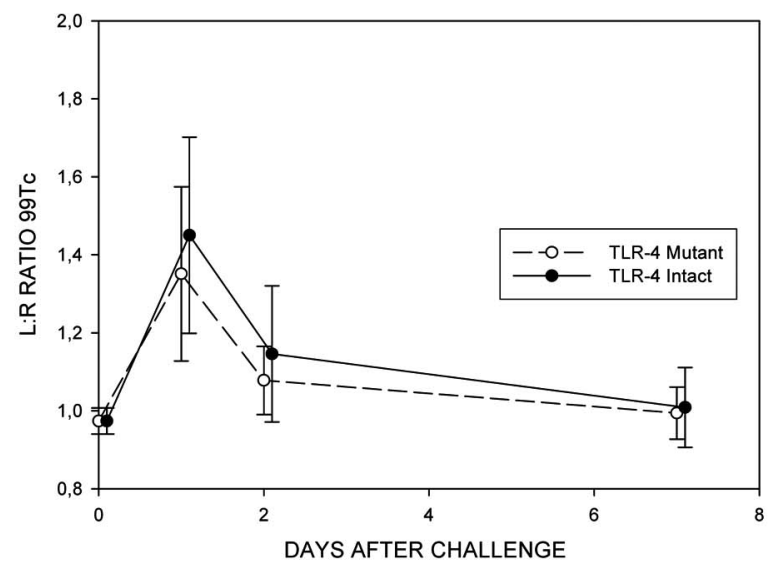

Fig. 1c

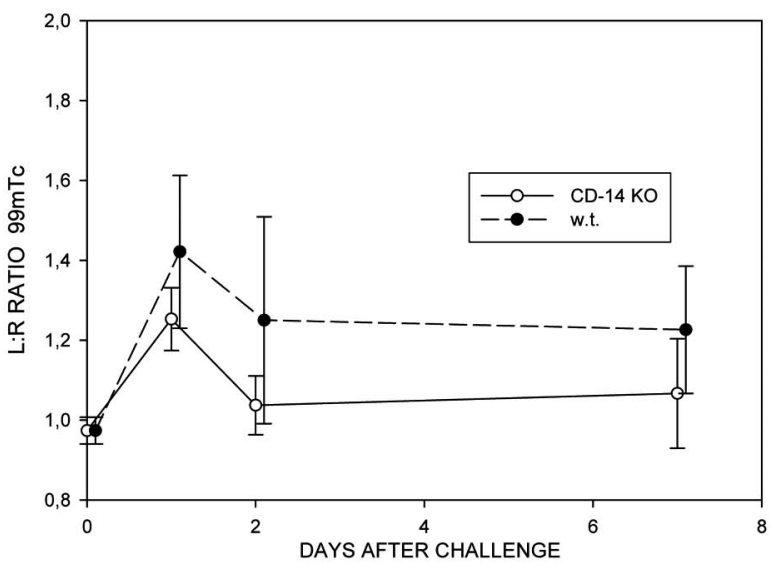

Fig. 1d

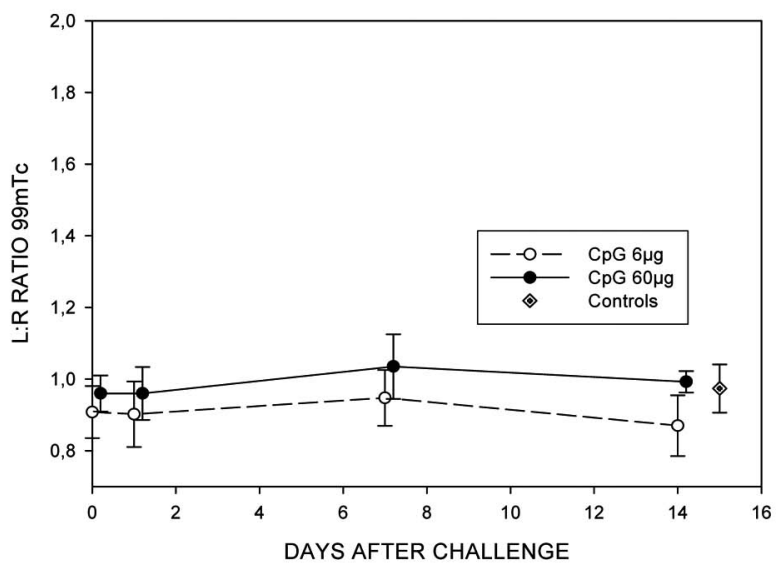

Fig. (1). 99mTc pertechnate uptake ratios in w.t. and TLR-2 -/- (a), TLR-4 -/- (b) and CD-14 -/- mice given lipidated OspA (c) and w.t. C57B1/6 mice given 6 or $60 \mu \mathrm{g}$ of CpG DNA (ODN 1668) (d). Differences in Fig. (1a) significant at all timepoints (day1 p<0.001, days 2,7 $\mathrm{p}<0.01)$; no significant differences in Fig. (2b-d).

(Fig. 2d) and 7 days. This set of experiments was repeated using a second batch of ODN 1668 with the same result. To exclude loss of activity of the ODN 1668 preparation being responsible for these negative results, we tested the ability of the ODN to stimulate B-cell cultures in parallel to the arthritis experiments. The ODN 1668 stimulated $80 \%$ of Bcells to blast formation, compared to only $6 \%$ blast formation in control cultures, demonstrating that, at the time the arthritis experiments were performed, the ODN retained full stimulatory activity.

\section{DISCUSSION}

It was previously shown that 2 recombinant, lipidated Outer surface proteins, A and C, from B. burgdorferi could induce severe joint injury in a rodent model [5]. There is accumulating evidence that bacterial lipoproteins like the borrelial Osps, exert their effects via TLRs [2]. The first part of this study looked at the role of several different pattern recognition receptors, known to be involved in innate immunity, on arthritis induction via Osp $\mathrm{A}$ from $B$. burgdorferi.

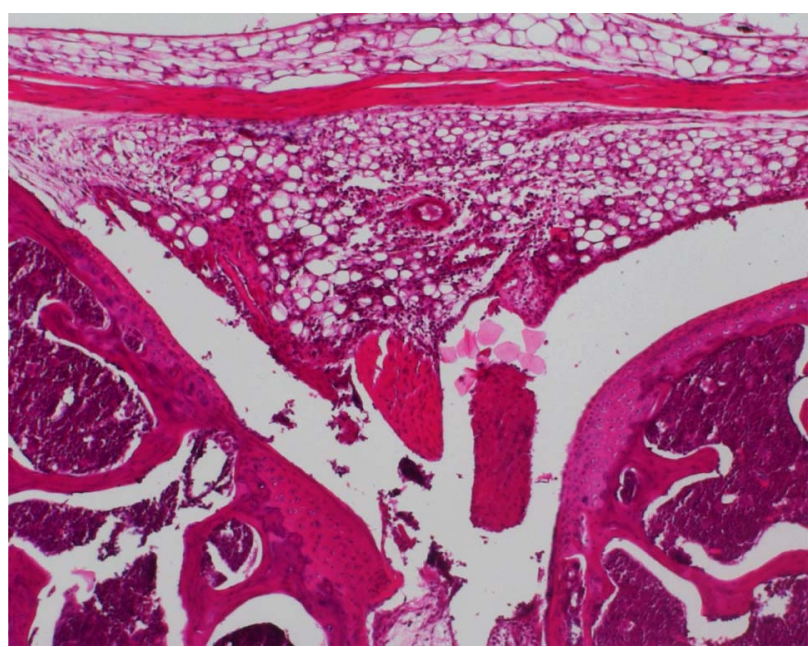

Fig. (2a). Joint section from TLR-2 ${ }^{+/+}$mouse given lipidated OspA. At day 2 massive cellular infiltration and cartilage destruction is seen (x10 H\&E). 


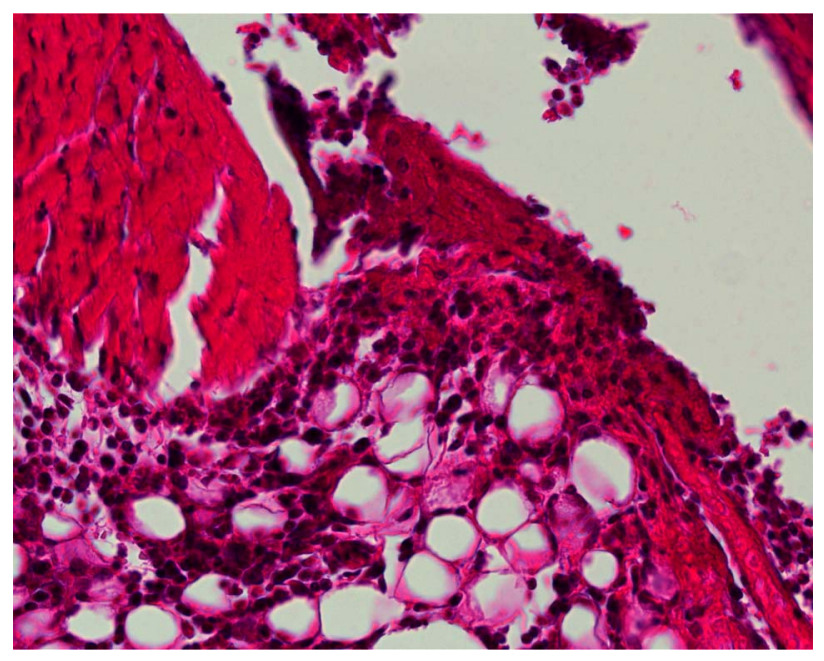

Fig. (2b). High power (x40) exert of Fig. (2a).

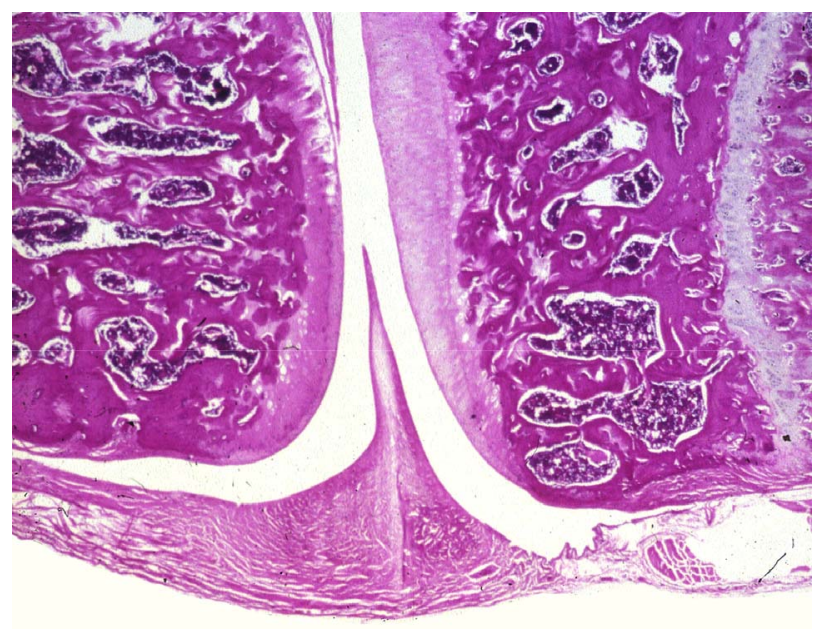

Fig. (2c). Joint section from TLR-2 -/- KO mouse given lipidated OspA. At day 2 minimal injury seen (x12 H\&E).

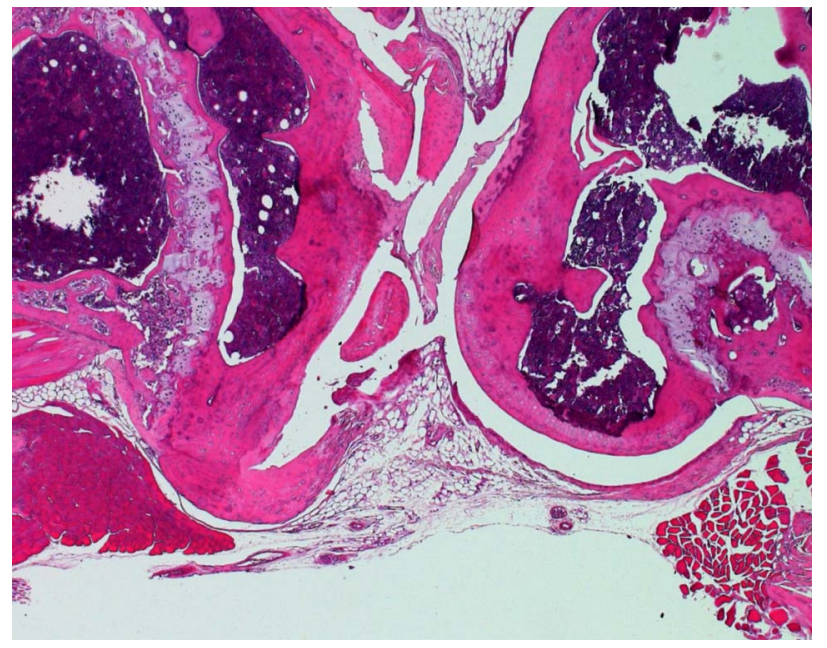

Fig. (2d). Joint section from w.t. C57B1/6 mouse given $60 \mathrm{~g} \mathrm{ODN}$ 1668 48h. previously, minimal injury seen (x10 H\&E).

These findings speak very clearly for the vital role of the TLR-2 receptor in induction of joint injury by the outer surface lipoprotein A of B. burgdorferi. Osp A is known to be a ligand for TLR-2, leading to activation of the NF- $\kappa B$ system and production of inflammatory cytokine profiles [6]. TLR-2 can form heterophilic dimers with other TLRs such as TLR-1 and TLR-6 [2], which helps to explain why TLR-2 recognizes such a wide range of microbial components. In addition to TLR-2, TLR-1 also seems to be involved in the recognition of Osp A [17], its relevance for induction of arthritis in the model employed was not tested.

It has been demonstrated that mice deficient in TLR-2 can harbour much higher levels of spirochetes and develop arthritis following infection [18]. This shows that TLR-2 is important for elimination of spirochetes, in its absence the spirochete burden can increase dramatically, this may then allow other mechanisms to come into play and result in arthritis. Thus multiple pathways could be involved in Lyme arthritis, their relative importance depending on spirochete burden levels.

In previous reports a scenario for the involvement of lipidated Osps in Lyme arthritis has been developed [4, 5]; the current data allow this to be extended. Spirochetes enter joints following hematogenic spread and TLR-2 receptors are engaged by Osp A, leading to acute, local inflammation. In joints, both synovial fibroblasts and chondrocytes have been shown to express TLR-2 [19, 20]. It was also recently shown that lipidated Osp A can provide direct antigen nonspecific co-stimulatory signals to T-cells [21], this effect may help initiate or amplify humoral and cellular immune responses to various other spirochetal antigens present in the joint and could also be involved in the induction of autoimmunity, in the case where T-cells with autospecificities are activated. In a further report [22], activation of TLR-2 was shown to regulate the function of neutrophilic granulocytes, the major inflammatory cell involved in the model described. These latter reports underline the complexity of the cellular interactions involved. In the ongoing discussion on the potential role of persisting borrelial antigens in host tissue, reviewed in [3], molecular mimicry leading to autoimmunity is currently in favour. However, no unequivocal evidence has been presented and the issue remains open. Concern has been raised that the Lyme disease Osp A vaccine might trigger arthritis, but controlled studies have not provided supporting evidence [23].

A TLR-2 pathway has been shown to drive joint inflammation in the streptococcal cell wall model in mice [24]. This latter and the current report suggest that TLR-2 pathways may play an important role in post-infectious arthritis. In these systems a massive infiltration of PMN into joints is seen, the hallmark of reactive arthritis.

The results presented here indicate that TLR-4 is not involved in induction of joint injury via lipidated Osp A. It can also be ruled out that the low level LPS contamination present in the Osp A preparations employed (20-40 ng/20 $\mu \mathrm{g}$ Osp A) induced a synergistic effect via TLR-4. TLR-4 is the classic receptor involved in signalling transduction by bacterial lipopolysaccharide $[25,26]$. In earlier reports TLR2 was also associated with cellular responses to LPS, but this was shown to be associated with contamination of the LPS preparations employed [27]. 
The results indicate that the joint injury induced by lipidated Osp A is largely CD-14 independent, as although CD-14 intact w.t. mice had somewhat higher levels of 99Tc uptake, the differences to $\mathrm{CD}-14 \mathrm{KO}$ mice never reached significance. Although in vitro studies have shown CD-14 mediated activation by $B$. burgdorfrei Osp to be a potentially important inflammatory pathway [28-30], it has been suggested that signalling via $\mathrm{CD}-14$ can in fact attenuate an inflammatory response to $B$. burgdorferi [31]. Possibly concomitant engagement of CD-14 results in a complex balance of pro- and anti-inflammatory pathway activation, ultimately determining the outcome of infection, but such mechanisms do not appear to be involved in the model described here. It cannot be excluded that the different strains of mice used may have varying susceptibility to arthritis induction, however use of wild and $\mathrm{KO}$ types with the same genetic backgrounds effectively minimises this aspect.

In the second part of the study, the effect of intraarticular administration of the TLR ligand, OD1668, was investigated. In our hands this $\mathrm{CpG}$ motif did not induce joint injury; how can this be reconciled with previous reports [9]? The histological changes reported by Deng, Tarkowski and co-workers after intra-articular injection of the same CpG motif employed here [9] consisted of synovial hypertrophy and limited cellular infiltration by cells having the morphology of macrophages, without any cartilage or bone destruction or pannus formation [32]. Massive neutrophilic granulocyte infiltration, the hallmark of classic gonarthritis, was absent in this model and the lack of a functional role for granulocytes was also confirmed by depletion experiments [33]. In this system, significant swelling of knee joints was also described [34], however, the increases in joint diameters reported, $0.09-0.23 \mathrm{~mm}$, were small (at most $5 \%$ of the original diameters). Thus the idea that bacterial DNA can induce changes analogous to human reactive/post-infectious arthritis in mice, is not really justified on the basis of the evidence reported. Interestingly, prior administration of bacterial Oligo-DNA, containing immunostimulatory $\mathrm{CpG}$ motifs, caused exacerbation of both collagen-induced [35] and adjuvant arthritis [36] in mice In an in vitro study, $\mathrm{CpG}$ ODNs failed to activate synovial fibroblasts, whereas stimulation with a TLR-2 ligand (bacterial peptidoglycan) led to up-regulation of TLR-2 and activation, including up-regulation of surface markers and the pro-inflammatory cytokines Il-6 and IL-8 [37].

TLR-2 clearly plays a central role in the induction of the acute inflammatory arthritis in mice seen following intraarticular injection of lipidated outer surface protein A from B. burgdorfei., Using CpG DNA motifs, which are ligands for TLR-9, we failed to induce joint injury in mice under the experimental conditions employed.

The results presented here add information concerning arthritis development in the absence of viable $B$. burgdorferi in host connective tissues. The notion that persistence of borrelial antigens rather than viable organisms is of significance has not gathered wide support [3], but deserves inclusion in concepts of chronification of Lyme arthritis. The idea that bacterial CpG DNA motifs may have more general relevance for post-infectious arthritis by stimulating TLR-9 receptors is intriguing, although we were unable to confirm the ability of a particular motif (ODN 1668) to induce arthritis in mice.

\section{REFERENCES}

[1] Corr M. The tolls of arthritis. Arthritis Rheum 2005; 52: 2233-6.

[2] Kawai T, Akira S. The role of pattern-recognition receptors in innate immunity: update on Toll-like receptors. Nat Immunol 2010; 11: 373-84.

[3] Nardelli DT, Callister SM, Schell RF. Lyme arthritis: current concepts and a change in paradigm. Clin Vaccine Immunol 2008; 15: 21-34

[4] Gondolf KB, Mihatsch M, Curschellas E, Dunn JJ, Batsford SR. Induction of experimental allergic arthritis with outer surface proteins of Borrelia burgdorferi. Arthritis Rheum 1994; 37: 1070-7.

[5] Batsford S, Dunn J, Mihatsch M. Outer surface lipoproteins of Borrelia burgdorferi vary in their ability to induce experimental joint injury. Arthritis Rheum 2004; 50: 2360-9.

[6] Hirschfeld M, Kirschning CJ, Schwandner R, et al. Cutting edge: inflammatory signaling by Borrelia burgdorferi lipoproteins is mediated by toll-like receptor 2. J Immunol 1999; 163: 2382-6.

[7] Harokopakis E, Hajishengallis G. Integrin activation by bacterial fimbriae through a pathway involving CD14, Toll-like receptor 2, and phosphatidylinositol-3-kinase. Eur J Immunol 2005; 35: 120110 .

[8] Manukyan M, Triantafilou K, Triantafilou M, et al. Binding of lipopeptide to CD14 induces physical proximity of CD14, TLR2 and TLR1. Eur J Immunol 2005; 35: 11-921.

[9] Deng GM, Nilsson IM, Verdrengh M, Collins LV, Tarkowski A. Intra-articularly localized bacterial DNA containing $\mathrm{CpG}$ motifs induces arthritis. Nat Med 1999; 5:702-5.

[10] Hemmi H, Takeuchi O, Kawai T, et al. A Toll-like receptor recognizes bacterial DNA. Nature 2000; 408: 740-5.

[11] Dunn JJ, Lade BN, Barbour AG. Outer surface protein A (OspA) from the Lyme disease spirochete, Borrelia burgdorferi: high level expression and purification of a soluble recombinant form of OspA. Protein Express Purification 1990; 1: 159-68.

[12] Werts C, Tapping RI, Mathison JC, et al. Leptospiral lipopolysaccharide activates cells through a TLR2-dependent mechanism. Nat Immunol 2001; 2: 346-52.

[13] Bernheiden M, Heinrich JM, Minigo G, et al. LBP, CD14, TLR4 and the murine innate immune response to a peritoneal Salmonella infection. J Endotoxin Res 2001; 7: 447-50.

[14] Mertz AK, Batsford SR, Curschellas E, Kist MJ, Gondolf KB. Cationic Yersinia antigen-induced chronic allergic arthritis in rats. A model for reactive arthritis in humans. J Clin Invest 1991; 88: 632-42.

[15] Kruijsen MW, van den Berg WB, van de Putte LB, van den Broek WJ. Detection and quantification of experimental joint inflammation in mice by measurement of $99 \mathrm{mTc}$-pertechnetate uptake. Agents Actions 1981; 11: 640-2.

[16] Lens JW, van den Berg WG, van de Putte LBA. Quantification of arthritis by $99 \mathrm{mTc}$-uptake measurements in the mouse knee joint: corelation with histological joint inflammation scores. Agents Actions 1984;14: 723-8.

[17] Alexopoulou L, Thomas V, Schnare M, et al. Hyporesponsiveness to vaccination with Borrelia burgdorferi OspA in humans and in TLR1- and TLR2-deficient mice. Nat Med 2002; 8: 878-84.

[18] Wang X, Ma Y, Weis JH, Zachary JF, Kirschning CJ, Weis JJ. Relative contributions of innate and acquired host responses to bacterial control and arthritis development in Lyme disease. Infect Immun 2005; 73: 657-60.

[19] Seibl R, Birchler T, Loeliger S, et al. Expression and regulation of Toll-like receptor 2 in rheumatoid arthritis synovium. Am J Pathol 2003; 162: 1221-7.

[20] Liu-Bryan R, Pritzker K, Firestein GS, Terkeltaub R. TLR2 Signaling in Chondrocytes Drives Calcium Pyrophosphate Dihydrate and Monosodium Urate Crystal-Induced Nitric Oxide Generation. J Immunol 2005; 174: 5016-23.

[21] Sobek V, Birkner N, Falk I, et al. Direct Toll-like receptor 2 mediated co-stimulation of $\mathrm{T}$ cells in the mouse system as a basis for chronic inflammatory joint disease. Arthritis Res Ther 2004; 6: 433-46.

[22] Sabroe I, Jones EC, Whyte MK, Dower SK. Regulation of human neutrophil chemokine receptor expression and function by 
activation of Toll-like receptors 2 and 4. Immunology 2005; 115: 90-8.

[23] Ball R, Shadomy SV, Meyer A, et al. HLA type and immune response to Borrelia burgdorferi outer surface protein a in people in whom arthritis developed after Lyme disease vaccination. Arthritis Rheum 2009; 60:1179-86.

[24] Joosten LA, Koenders MI, Smeets RL, et al. Toll-like receptor 2 pathway drives streptococcal cell wall-induced joint inflammation: critical role of myeloid differentiation factor 88. J Immunol 2003; 171:6145-53.

[25] Poltorak A, He X, Smirnova I, et al. Defective LPS signaling in $\mathrm{C} 3 \mathrm{H} / \mathrm{HeJ}$ and $\mathrm{C} 57 \mathrm{BL} / 10 \mathrm{ScCr}$ mice: mutations in Tlr4 gene. Science 1998; 282: 2085-8.

[26] Hoshino K, Takeuchi O, Kawai T, et al. Cutting edge: Toll-like receptor 4 (TLR4)-deficient mice are hyporesponsive to lipopolysaccharide: evidence for TLR4 as the Lps gene product. J Immunol 1999; 162: 3749-52.

[27] Hirschfeld M, Ma Y, Weis JH, Vogel SN, Weis JJ. Cutting edge: repurification of lipopolysaccharide eliminates signaling through both human and murine toll-like receptor 2. J Immunol 2000; 165 : 618-22.

[28] Giambartolomei GH, Dennis VA, Philipp MT, et al. Borrelia burgdorferi stimulates the production of interleukin-10 in peripheral blood mononuclear cells from uninfected humans and rhesus monkeys. Infect Immun 1998; 66: 2691-7.

[29] Wooten RM, Morrison TB, Weis JH, Wright SD, Thieringer R, Weis JJ. The role of CD14 in signaling mediated by outer membrane lipoproteins of Borrelia burgdorferi. J Immunol 1998; 160: $5485-92$.
[30] Sellati TJ, Bouis DA, Caimano MJ, et al. Activation of human monocytic cells by Borrelia burgdorferi and Treponema pallidum is facilitated by CD14 and correlates with surface exposure of spirochetal lipoproteins. J Immunol 1999; 163: 2049-56.

[31] Benhnia MR, Wroblewski D, Akhtar MN, et al. Signaling through CD14 attenuates the inflammatory response to Borrelia burgdorferi, the agent of Lyme disease. J Immunol 2005; 174: 1539-48.

[32] Deng GM, Tarkowski A. The features of arthritis induced by $\mathrm{CpG}$ motifs in bacterial DNA. Arthritis Rheum 2000; 43: 356-64.

[33] Deng GM, Verdrengh M, Liu ZQ, Tarkowski A. The major role of macrophages and their product tumor necrosis factor alpha in the induction of arthritis triggered by bacterial DNA containing CpG motifs. Arthritis Rheum 2000; 43: 2283-9.

[34] Zeuner RA, Verthelyi D, Gursel M, Ishii KJ, Klinman DM. Influence of stimulatory and suppressive DNA motifs on host susceptibility to inflammatory arthritis. Arthritis Rheum 2003; 48: 1701-7.

[35] Miyata M, Kobayashi H, Sasajima T, Sato Y, Kasukawa R. Unmethylated oligo-DNA containing $\mathrm{CpG}$ motifs aggravates collagen-induced arthritis in mice. Arthritis Rheum 2000; 43: 257882.

[36] Ronaghy A, Prakken BJ, Takabayashi K, et al. Immunostimulatory DNA sequences influence the course of adjuvant arthritis. J Immunol 2002; 168: 51-6.

[37] Kyburz D, Rethage J, Seibl R, et al. Bacterial peptidoglycans but not $\mathrm{CpG}$ oligodeoxynucleotides activate synovial fibroblasts by toll-like receptor signaling. Arthritis Rheum 2003; 48: 642-50.

(C) Batsford et al.; Licensee Bentham Open.

This is an open access article licensed under the terms of the Creative Commons Attribution Non-Commercial License (http://creativecommons.org/licenses/by-nc/ $3.0 /$ ) which permits unrestricted, non-commercial use, distribution and reproduction in any medium, provided the work is properly cited. 